\title{
Alternative Service Delivery Arrangements at the Municipal Level in Slovenia and Croatia
}

\author{
BOŽO GRAFENAUER \& MiRKO KLARIĆ
}

\begin{abstract}
There has been extensive development and rapid expansion of alternative forms of public service provision at the local level in Slovenia and Croatia over the last twenty years. During that time, the private sector began to be intensively involved in performing public service activities and in investment financing for the public infrastructure construction, i.e., by the gradual introduction of the new forms of cooperation between the public and private sectors. However, the new Public-Private Partnership Act, which came into force in Slovenia in 2007 and in Croatia in 2008, signified a milestone in the legal regulation of alternative forms of public service delivery. The Act introduces European comparable arrangements and forms of public-private partnerships that can be either contractual or equity-based. Within public services, local public goods and services are mostly provided by public enterprises and institutions, and by awarding public service concessions. Other forms of public-private partnerships primarily include some forms of build-operate-transfer project financing.
\end{abstract}

KEYWORDS: - local authorities • local self-government • local public services $\cdot$ public-private partnerships $\bullet$ concession $\cdot$ Slovenia - Croatia

\footnotetext{
CORRESPONDENCE AdDRESS: Božo Grafenauer, Ph. D., Associate Professor, University of Maribor, Faculty of Law, Mladinska ulica 9, 2000 Maribor, Slovenia, email: bozo.grafenauer@uni-mb.si. Mirko Klarić, Ph. D., Assistant Professor, University of Split, Faculty of Law, Domovinskog rata 8, 21000 Split, Croatia, email: mirko@inet.hr.
} 


\section{Introduction}

With service development, the scope of society-relevant goods increases. These public goods are provided within the framework of the public service system. At the same time, there is emerging an increasing number of forms and modes of performing public services. While at the end of the $19^{\text {th }}$ century and at the beginning of the $20^{\text {th }}$ century, the classical theoreticians of administrative management were primarily substantiating the public service provision provided by administrative bodies of the state and local communities, which is defined as a traditional or classical form of the provision of public goods and services (Wilson, 1887: 197-222), there were also other forms of public service provision that were gradually developed within the framework of the independent (or specialised) entities under public and private law. In the 1980s, there was an exceptional increase in public-private partnerships in the construction of public infrastructure and in public service provision. This development was primarily influenced by economic reasons for the implementation effectiveness of public-significant investments and public service provision, as well as technology development and state and local budget constraints. All of this has contributed to a greater involvement of private enterprises and capital in performing the services of general economic interest and non-economic services of general interest ${ }^{1}$. By involving the private sector in funding infrastructure projects and public service provision, the public sector is able to obtain sufficient resources to develop infrastructure, equipment, and technologies without having to take on any debt. At the same time, through better private sector management and operation, the public sector is able to provide more effective, better and cheaper public service delivery. With service development, there has been a move from the traditional forms of public service delivery (provided by administrative services of the state and local communities) to new alternative service delivery arrangements. In practice, a series of organisational forms of public service provision can be seen within the state and local communities. It is characteristic of them that they are funded directly through the Budget, that they employ civil servants, that the founder's rights are not transferable, that special rules have been laid down for operation, and that they are under the direct control of the political authority (Brezovnik, 2008:145). By involving the private sector in project financing for investments in public infrastructure construction and in public service provision, some new forms of cooperation between the public and private sectors were gradually introduced in the public-private partnership (see Tičar \& Zajc, 2010). In addition, the need for effective public service delivery in certain areas also encouraged the emergence of various forms of cooperation in the public sector within a public-publicpartnership.

We can say that in the past development of public services, the basic guiding principle was to establish a greater openness to organising public service providers and to enhancing the efficiency of public service provision, as well as to introducing some new institutional forms of organisation. With service 


\section{LEX LOCALIS - JOURNAL OF LOCAL SELF GOVERNMENT B. Grafenauer \& M. Klarić: Alternative Service Delivery Arrangements at the Municipal Level in Slovenia and Croatia}

development, the role of government and local communities has remained particularly important in regulating and controlling the public service. Various new forms and modes of public service delivery have emerged for providing adequate infrastructure, technology, equipment, and public services themselves.

At the EU level, there is no uniform binding regulation that would lay down the general legal framework for performing public-service activities in the European Union, i.e., for providing public goods within the framework of public services, public service providers' obligations, forms of public service provision, and modes of funding. Thus, the EU Member States and their local communities are in principle free to decide what products and services need to be provided in the public interest under a special legal regime applicable to the public service, as well as which method and organisation of performing these activities need to be chosen. However, it is necessary to point out to the White Paper on Services of General Interest (COM (2004) 374 final of 12.5.2004) in which the European Commission underlined that the services of general interest are of particular importance for the EU, and their efficient and non-discriminatory provision is the condition for the efficient functioning of the single market in the European Union. Of course, when establishing the legal regime of public services, the EU Member States must observe the principles of EU law (e.g., non-discrimination principle and the principle of free access to services) and the rules governing the internal market, protection of competition, equality of choice, and procedure transparency. In the EU rules governing the contractual relationships between the public and private sectors, it is indicated that, to the greatest extent possible, these relationships must be provided by the public procurement rules (Krajnc, 2009: 200). Therefore, it is clear that the Slovenian and Croatian statutory regulation in principle also follows the Public Procurement Directives.

When regulating public services in a country, the lawmaker's basic obligation is to determine the activities to be carried out in the public interest, and how the public service regime is regulated depends on this interest. Public services also include the determination of their implementation forms. Thus, it is necessary to determine: economic and non-economic activities where individual public goods must be compulsorily provided (public service obligation); pricing and other economic conditions for performing activities; forms of public service provision (organisation of public service provision). Within the limits of the rules of EU law, the EU Member States are free to choose activities, organisational forms, and public service provision modes. They independently decide which public service activities will be performed, and also whether these activities will be performed by the state or by the local communities themselves (in-house service providers), or they will be performed by other legal entities of public or private law. Public service providers can be: (1) the state, municipalities or wider self-governing local communities (core public bureaucracy), (2) specialised public entities (independent public enterprises, public undertakings), (3) private law entities (private independent enterprises, public undertakings). 


\section{New Legislation on Public-Private Partnership in Slovenia and Croatia}

The new Public-Private Partnership Act, which came into force in the Republic of Slovenia ${ }^{2}$ in March 2007 and in the Republic of Croatia ${ }^{3}$ in November 2008, signified a milestone in the legal regulation of alternative forms of public service delivery in both countries. When this Act was being drawn up, the European Commission's Guidelines for Successful Public-Private Partnership (March $2003),{ }^{4}$ the Green Paper on Public-Private Partnerships, and Community Law on Public Contracts and Concessions (Brussels, 30 April 2004, COM (2004) 327 final) were observed. In addition, it should be indicated that also some other rules of the European Union and international organisations (for more information, see Kranjc, 2009: 201, 204) apply to the public-private partnership. It needs to be pointed out that prior to adopting the Act, several acts and specialised papers referring to these problems ${ }^{5}$ were published in both countries.

The statutory regulation of the public-private partnership was adopted relatively late in both countries. So, it is not surprising that the Act contributed significantly to the development of the legally foreseen forms of the public-private partnership primarily in the basic and wider self-governing local communities (i.e., in municipalities and counties). This is particularly important because for population, the decisive performance criteria of municipalities are how the resolving of certain problems and issues is in fact provided in the fields of basic education and childcare, primary health care, drinking water supply, drainage and wastewater treatment, municipal waste management, public area planning and cleaning, road maintenance, parking area management and planning, etc. The duties of municipalities and their bodies are to serve the local population interests and to deal with resolving the issues associated primarily with the daily interests and needs of the people, i.e., with the daily life of the population in its narrow local environment on which the service quality has a decisive impact within the framework of the services of general economic interest and non-economic services of general interest (Grafenauer \& Brezovnik, 2006: 336). It needs to be pointed out that we have a one-level local self-government system in Slovenia because there are only 210 municipalities as basic self-governing local communities, while the provinces or regions (being supposed to administer local matters of broader importance and to carry out statutory tasks of regional importance) have not yet been established, although the Constitution of the Republic of Slovenia provides for them. In the Republic of Croatia, there are 555 municipalities as basic selfgoverning local communities, as well as 20 counties and the capital as selfgoverning regional communities.

In municipalities (a range of daily indispensable goods and services are primarily provided in municipalities as the basic self-governing local communities) quite some time prior to adopting the Public-Private Partnership Act, there were reflections on contemporary ways of securing project implementation funding in 
the fields of municipal infrastructure and other public sector development projects, as well as in the area of public service delivery. The reflections were on the most varied forms of cooperation between the public and private sectors within the public-private partnership model for funding public sector projects, and for public service delivery. The reason for this lies in the fact that the private sector is frequently more efficient than the public sector. Therefore, it is able to more efficiently make project investments. In addition, it also provides better and cheaper services. During the last few decades, the expansion of demand for public-private partnership for funding infrastructure projects has mainly been influenced by rapid development, demands and needs for quality services on the one hand and limited possibilities of budgetary funding of infrastructure on the other. In addition to the severe economic crisis that erupted in 2008, quite restrictive legislation on municipal borrowing ${ }^{6}$ also affects the possibility of providing budget funds. This is especially relevant if it is necessary to make longterm investments with high investment costs. In such a case, a public-private partnership needs to be taken into consideration as a non-fiscal instrument of funding public interest work (Šimovic, Lugarić-Rogić, Šimonić \&Vuletić-Antič, 2007: 171-202).

By providing high-quality public goods and services, the local self-government essence is being exercised. It lies in "the right and ability of local authorities to legally regulate and administer the essential part of the public matters within the framework of their tasks and to the benefit of the local population as laid down in Article 3 of the European Charter of Local Self-Government. The provision of high-quality public services is one of the basic tasks of municipalities. So, it is understandable that especially municipalities have pointed out to the unsatisfactory exploitation of the possibility for providing more quality services of general economic interest - this is primarily in relation to public-private partnerships for implementing the projects in the areas of construction, maintenance, and use of municipal infrastructure, as well as in relation to the delivery of public municipal services. The construction of municipal facilities and the direct provision of services within the public service delivery system are frequently closely connected because the private sector's interest is to construct individual facilities and municipal infrastructure for which the private sector in return acquires the right to perform public services for a certain period of time, i.e., to provide public goods to the direct users.

It is important that the Slovenian and Croatian Public-Private Partnership Act explicitly points out to the municipal powers regarding the regulation, management, and provision of local public services. In principle, the municipality enters the public service sphere as a regulator of public service activities in the same way as the state does. The municipality may also enter the public service sphere as a public service provider (if it performs the services by itself at its own expense) or as an owner or co-owner of capital shares, or as a founder or cofounder of any legal entities (either of public or private law). 
When dealing with the public service delivery, we need to take into account the fact that both Slovenia and Croatia were incorporated into the Socialist Federal Republic of Yugoslavia until 1991, which was, of course, also reflected in the then specific regulation of providing and implementing public services under the conditions of the socialist regime in which there was, inter alia, a specific type of ownership, i.e., social ownership. The first few decades after the Second World War were characterised by the public service activities that were carried out directly within the framework of the state, municipal administration, and in stateand municipally-owned companies and institutions. The contemporary European comparable forms and modes of the public service delivery emerged as late as the last twenty years. Today, the most prevalent attitude is that the role of the state and municipalities is necessary in terms of a "regulator." However, it is not necessary when it comes to the direct service providers. If until recently, the indicated activities were carried out by the state or municipalities (by themselves or through their companies or public institutions), in public service delivery today, contemporary economic and market-managerial approaches are increasingly adhered to. And there are more and more options for the private sector business entities to carry out these activities.

Before the Public-Private Partnership Act came into force (in Slovenia in 2007 and in Croatia in 2008), the possibility of cooperation between the public and private sectors in providing public goods within the public service delivery system had been regulated under two basic or umbrella Acts. The activities that have the character of public services, or they are carried out as public services, have been specified in a range of sectoral laws. Two Acts govern public service delivery methods and forms. In Slovenia, these two Acts are:

- The Public Utilities Act (1993) under whose provisions public utilities provide public material goods such as products and services whose uninterrupted and smooth production (that is in the public interest) is provided by the state or municipalities, or by other local communities to meet public needs if the provision of public goods cannot be secured in the market. The compulsory services of general economic interest shall be provided by law. ${ }^{7}$ In municipalities, the public service delivery method is governed by the municipal ordinance. When summarising the analysis data (Grafenauer, 2009: 209-219) of the forms of public service delivery in municipalities, we can ascertain that public utility services are carried out in the following manner: in public enterprises and by awarding public service concessions (this Act gives the possibility of carrying out the public utility services in public economic institutions, public enterprises, by awarding public service concessions, and through the public sector capital investment in the private sector).

- The Institutes Act (1991) governs non-economic services of general interest in the fields of education, science, culture, sports, health care, 
social care, childcare, disability policy, etc. if the purpose of carrying out activities is not to generate profit. When establishing institutes, in addition to this umbrella Act, the relevant legislation shall be observed. This Act distinguishes between the public institutes (established by the state or municipalities to perform services of general interest) and other institutes that may also perform services of general interest, but only on a concession basis.

In the Republic of Croatia, the provision of public goods within the public service delivery system is also regulated under two basic Acts that govern public service delivery methods and forms:

- The Municipal Utility Services Act (1995) provides municipal utility activities performed as public services, and the method of performing them, e.g., drinking water supply, drainage and wastewater treatment, gas supply, heat energy supply, public passenger transport services, cleanliness maintenance, municipal waste disposal, maintenance of public areas, roads maintenance, small marketplaces, cemeteries and crematoria maintenance, chimney sweep services, public lighting. Article 4 of the Act provides the modalities of carrying out these activities. They can be performed by (1) companies established by local government units, (2) public institutions set up by local government units, (3) individual services established by local government units, (4) natural or legal entities holding a concession, (5) natural or legal entities holding municipal service provision contracts. The Act also contains provisions on financing municipal infrastructure facilities for which the potential financial resources are: utility payments, municipal budget funds, and concession remuneration.

- The Institutes Act (1993) provides that institutes are established for carrying out permanent activities (e.g., education, science, culture, health care, childcare, etc.) if the purpose of carrying out these activities is not to generate profit. In addition to this umbrella Act, the relevant legislation ${ }^{8}$ should be observed also in Croatia when establishing institutes. If the indicated activities are conducted as public services, public institutes are established by the state, counties, and municipalities (they can also be set up by other natural or legal entities if this is expressly provided by law). It is important to point out to the statutory provision that prior to adopting the ordinance on establishing a public institute, the municipality or county should obtain the line ministry's opinion whether the establishment complies with law. If an activity is required to be carried out solely on the basis of concessions, permits, consents or other acts of the competent body, then it may be entered in the Register of Companies only on the basis of a valid concession contract, or a final decision on the permit or approval of the competent body. 
Before showing some content characteristics of the Slovenian and Croatian Public-Private Partnership Act, it needs to be ascertained that the public-private partnership is formally a new legal institution in Slovenia and Croatia. However, in both legal orders, it has existed (with regard to its content) in individual forms (implemented in the state and local administration, in public enterprises and institutions on a concession basis) under other names for nearly 20 years. The new Public-Private Partnership Act is actually a lex generalis in relation to services of general economic interest and non-economic services of general interest. But on the other hand, other applicable legislation is applied as a lex specialis (e.g., the Public Utilities Act in Slovenia and the Municipal Utility Services Act in Croatia, as well as a series of sectoral laws).

In Slovenia, Article 3 of the Public-Private Partnership Act provides that this Act applies to the procedures for establishing and implementing public-private partnership with regard to the issues that are not regulated by a special statute or by this statute-based regulation of individual forms of public-private partnership. This Act applies as a lex generalis, and sectoral laws or special statutes are applied on the general legal (doctrinaire) principle lex specialis derogat legi generali. Although the Public-Private Partnership Act contains provisions on applying the rules for the implementation of contractual partnership agreements (it provides that this Act and/or the Public Utilities Act shall be applied), and for the exercise of the equity-based partnership (it provides that this Act, the Public Utilities Act, and the Public Finance Act shall be applied), there are still a number of issues and unclear situations in daily practice, which were highlighted by some authors of the comments on the Act. They were published in 2007 (Bohinc, Mužina \& Tičar, 2007) and in 2009 (Kranjc, Kerševan, Plauštajner \& Prelič, 2009).

\section{Some Content Characteristics of the Slovenian and Croatian Public- Private Partnership Act}

Public-private partnerships include legal relationships created, in the public interest, between the public and private sectors. The public-private partnership implies that there are contractual or equity-based partnerships between the state, local communities, and private law entities to provide funding for the construction of the necessary public facilities and installations, or to provide services to users within public service provision.

There are various forms of public-private partnerships, depending on the type of private sector involvement in funding infrastructure construction and/or public service provision. They are distinguished by how the public and private sector responsibilities are distributed with regard to asset ownership, management and maintenance, capital investments, and commercial risk. In practice, the most frequent arrangements are combinations of two or more partnership forms. In both theory and legislation, there are two basic forms of public-private partnerships (see Haarmeyer \& Mody, 1999: 61-64; Gazvoda \& Mrak, 2005: 31-38). 
- Contractual public-private partnership that is based on an obligation contract. It includes various forms of private sector management participation where the infrastructure remains in ownership of the public sector, and public service delivery is entrusted to private-sector contractors, or services of general interest are fully performed within the private sector into whose temporary or permanent ownership the infrastructure passes. Contractual partnerships may include: service delivery contracts, management and operation contracts, leasing contracts, traditional concession contracts, forms of project funding, e.g., the model of Build-Operate-Transfer or BOT.

- Equity-based public-private partnership that refers to a partnership based on a legal status or on a property in a common legal entity. Public and private partners may create an equity-based public-private partnership by setting up legal entities of public or private law, and through various other forms of equity-based partnerships, sale or purchase of shares, transfer of rights and entitlements.

The Slovenian Public-Private Partnership Act is fairly extensive because it has as many as 154 articles. The Act lays down the purposes and principles of private investment in public projects, and of public funding of the private sector projects in the public interest, stipulating the methods of promoting public-private partnerships, the conditions, the formation process, the forms and methods of implementing public-private partnerships, specifying the particularities of construction and service delivery concessions, the equity-based public-private partnership characteristics, control over public-private partnerships, transformation of public enterprises, settlement of disputes, jurisdiction of courts and arbitral tribunals to rule on disputes arising from these relationships (as provided in Article 1 of the Act). The Act provides that the public-private partnership may be implemented

- as a contractual partnership that takes the form of a concession partnership (i.e., a bilateral legal relationship between the state and a local community or other entity of public law as between a grantor and a legal or natural entity as a concessionaire [for more information, please see Pirnat, 2007] to whom the grantor grants the special or exclusive right to perform services of general economic interest or other activities in the public interest, which may include the construction of facilities and installations that are partly or entirely in the public interest) or as a public procurement partnership (i.e., an onerous relationship between the ordering party and the supplier of goods or services, building contractor or service provider whose objects are supply contracts, execution of construction projects and services);

- as an equity-based partnership. The Act provides that the equity-based public-private partnership is a relationship entered into between the 
public and private partners in a manner that the state, one or more local self-governing communities, or other entities of public law, or other public partners grant the exercise of rights and obligations arising from the public-private partnership to the equity-based public-private partnership contractor by establishing a legal entity under the conditions laid down by law, by selling a share of a public partner in the public enterprise or in other entity of public or private law, by buying a share in an entity of public or private law, through recapitalisation, or in another manner that is legally and actually similar and comparable to the indicated forms, and by transferring the rights and obligations arising from the public-private partnership to this entity (e.g., performing public utility services, etc.).

In accordance with statutory provisions, the Public-Private Partnership Department operates within the Ministry of Finance. This department develops, monitors, and participates in implementing public-private partnership in the Republic of Slovenia. In addition, it prepares the PPP implementation manuals; it develops professional proposals for amending regulations, and for taking other measures that may have an impact on improving practice and on eliminating the problems in this field; it keeps records on the public-private partnership projects, thereby monitoring them and offering expert assistance to public partners at the state or local levels. Under the indicated provisions, the Minister of Finance has issued the rules on the content and mode of keeping records on the public-private partnership projects and on the contracts concluded within the framework of the public-private partnership.

The competent body of the public partner (this is the government in the state, and in a municipality, this is the local council) is the one that takes a decision on determining the public interest in establishing a public-private partnership, and in carrying out a project in one of the public-private partnership forms. During the selection process, it takes also other decisions for which it is competent. When choosing the mode of carrying out the project that can be the subject of the publicprivate partnership, the public partner must ascertain whether the project is suitable for the public-private partnership (project feasibility assessment and comparison of variants), thereby acting in accordance with the Rules on the Content Eligibility of a Particular Project under the public-private partnership model. These Rules lay down the content of the documentation to be prepared by the public partner. It must include conceptual solutions to achieving the announced objectives, and technical specifications; an analysis of development opportunities and investor capability assessment; the estimated value of the investment and the anticipated financial construction that shows the risks the interested person would take; an economic evaluation of the project; the project implementation schedule, and the revenue and expenditure estimates in the project life cycle. 
The procedure for granting a public-private partnership is uniform for all entities. In the initial stages, the procedure is equal irrespective of whether it is about a contractual public-private partnership or an equity-based public-private partnership (Brezovnik, 2008: 208). The Public-Private Partnership Act governs the procedure for granting a public-private partnership in four stages:

- the preliminary procedure process during which the public partner takes the decision to enter into a public-private partnership, and thereby sending out a public call to promoters;

- adoption of the Public-Private Partnership Act (it sets out the subject, the rights and obligations of public and private partners, the procedure for selecting a private partner, and other components of a public-private partnership relationship);

- public tender procedure that includes mandatory electronic notification of invitation to tender, definitions of terms and rules of the competitive dialogue procedure, public tender obligations, public tender content, technical specifications, selection criteria, the language and operating rules of the public partner technical committee;

- the procedure for selecting the public-private partnership contractor: submitting and opening tenders, review and evaluation report, the act of choice (if the subject of the public-private partnership is the concession for the provision of services of general economic interest, and for other activities where due to the protection of the public interest, the Act expressly provides issuing an administrative decision, then the act of choice is an individual administrative act under which the selected private partner shall conclude a PPP agreement pursuant to Article 57 of the Act), and legal protection against this act and the conclusion of the agreement.

The Croatian Public-Private Partnership Act is much less extensive. It includes only 45 articles that govern the procedure for preparing, proposing, and approving the public-private partnership projects, the rights and obligations of the public and private partners, as well as the establishment and competences of the PublicPrivate Partnership Agency. The Act distinguishes

- a contractual public-private partnership that is a PPP model where the two partners set out their mutual rights and obligations in implementing the public-private partnership project on an agreement basis. The agreement content is defined in a special Regulation Governing the PPP Agreement Content adopted by the Government of the Republic of Croatia. The agreement is concluded for a period of 5 to 40 years. All the concluded agreements shall be entered in a special PPP Agreement Register. This Register is kept in the Public-Private Partnership Agency. The procedure for proposing, approving, and implementing the PPP 
projects is described in detail in the Act. The said Regulation contains some implementation provisions.

- $\quad$ an equity-based public-private partnership that is based on an ownership or founding relationship between public and private partners in the joint company that is the project implementation provider. The ratio between public and private partners can be based on the founding stake in the newly founded company. In the existing company, it can be on an equity purchase basis. Also for this PPP form, the law provides the procedure for its realisation.

The Public-Private Partnership Agency has been established as a legal entity with public law powers at the state level in the Republic of Croatia. It carries out the procedures for evaluating and approving project proposals for a public-private partnership, application documentation, and the final proposal for the PPP agreement. This agency is the central government body responsible for implementing the Public-Private Partnership Act. The Agency performs its tasks on the basis of the statutory powers. The Government adopted a special Regulation on Criteria for Evaluating and Approving the PPP Projects, and the Regulation on Control over the PPP Project Implementation (2009). The Agency has relatively great powers so that we can speak about a kind of state-centralised care for implementing the Public-Private Partnership Act in everyday practice. This is especially important because the Agency acts are final, and no administrative dispute against them shall be instituted.

The Public-Private Partnership Agency, founded by the Government of the Republic of Croatia, plays a decisive role in implementing a public-private partnership in practice. Laws and regulation specifically regulate the procedure for proposing, approving, and implementing the public-private partnership projects. Here are some procedural characteristics: after obtaining approval from the Ministry of Finance for each individual PPP project (the project is in line with budget projections, plans, and fiscal risk), and after obtaining an opinion of the authorities of local communities (whether or not the project complies with the plans of local community development policy, i.e., municipalities and regions), the Agency issues a decision approving the PPP project implementation under the proposed partnership implementation model. Each project achieves the status of the PPP project only on the basis of this decision. Only then may the public partner decide on the project implementation by initiating the procedure for selecting a private partner. Also, during a further procedure, the Public-Private Partnership Agency role is decisive because the Agency is competent to issue the decision that all tender documentation is prepared in line with the approved project, which allows carrying out the procedure for seeking a private partner. Prior to concluding the public-private partnership agreement, the Agency shall issue a decision approving the final wording of the PPP agreement. In addition, the public sector partner shall also obtain approval from the Ministry of Finance. In accordance with the express statutory provision, the procedure for selecting the 
private partner shall be carried out according to the public procurement rules. When it comes to the award of a PPP concession, the procedure shall be carried out in accordance with the rules laying down the concession award procedure (Gjidara \& Šimec, 2000). Also, regarding the equity-based public-private partnership, the Public-Private Partnership Agency role is defined by law. The Agency has the competence to issue rulings and approvals (in principle, its competence is identical to that indicated in the contractual public-private partnership). Anyway, the equity-based public-private partnership, especially in relation to concluding partnership agreements, shall be subject to the laws governing obligations, and to the laws governing the formation and operation of companies.

\section{Conclusion}

Alternative forms of public service delivery, including different types and forms of public-private partnership, began to develop intensively in Slovenia and Croatia in the nineties. Although an umbrella regulation, i.e., the Public-Private Partnership Act, came into force in Slovenia as late as 2007, and in Croatia in 2008 , individual forms of public-private partnership in relation to public service delivery had already existed under different names. It needs to be especially pointed out that the services of general economic interest provide daily necessary goods and services to the residents in local communities. In addition to the fact that municipalities mostly provide services of general interest within their public enterprises, the public service provision has rapidly increased thanks to granting concessions in municipalities during the last decade. Other innovative forms of cooperation between the public and private sectors (particularly when it is necessary to carry out investments in the public infrastructure construction) were gradually establishing themselves. It needs to be pointed out that the concession is characterised by a direct connection between the private partner and the residents who use and pay for public services. In the traditional mode of public service delivery, there is a relationship between public authorities (the state and municipalities) and residents as users, whereas in concession-based provision of public services, there is a new relationship, i.e., the relationship between the private person as a public good provider and the resident as a user (Smyth \& Wearing, 2002). Also, therefore, in such types of public-private partnerships, the regulatory and supervisory role of the state and local communities continues to be important.

Since the EU rules do not always attach such significance to the concession concept as it is in the law of individual countries, it should be noted that the Slovenian Public-Private Partnership Act defines the concession partnership as a bilateral legal relationship between the state or local self-governing community, or other entity of public law as a grantor and the legal or natural entity as a concessionaire where the grantor grants a special or exclusive right to the concessionaire to perform services of general economic interest or other activities 
in the public interest, which may also include the construction of facilities and installations in the public interest. The Act draws a distinction between service concession arrangements ${ }^{9}$ and concession-based construction where it provides that, if the public partner bears most or all of the business risk of carrying out the PPP project, such a relationship is considered as a public procurement relationship. Therefore, the public procurements rules shall be applied. For distinguishing reasons, it is important to know which party bears the business risk of carrying out business or project activities.

The data from the Public-Private Partnership Department of the Ministry of Finance of the Republic of Slovenia indicate that, to the largest extent possible, service concessions have been awarded at the local level. But there are very few complex forms of public-private partnership that would also include the construction of advanced infrastructure facilities. According to these data ${ }^{10}, 77$ $(37 \%)$ out of 210 municipalities have not entered into any concession relationships. 49 municipalities have entered into one single concession relationship. One municipality has 14 concessions, which is the highest number. The concession relationships most frequently entered into are for the following services of general economic interest: waste transport and disposal (45), drinking water supply and wastewater treatment (57), funeral and cemetery services (55), natural gas distribution (58), municipal road maintenance (38), etc. In the field of non-economic services of general interest, most concession relationships have been entered into for the provision of the basic health care services; there are 1557 relationships of this type (most of them are in urban municipalities; there are 11 such municipalities in Slovenia). A similar situation is in Croatia because in local communities, municipal utility activities are mainly carried out by companies, i.e., by municipal utility companies established by local communities (they must have majority ownership in them), public institutions, and by the legal entities that have obtained a concession for carrying out municipal utility activities (Sarvan, 2008: 1075). Some people believe that these activities could be performed more effectively by an unavoidable privatisation of public utility services so that the most favourable providers can conclude contracts with local communities to provide municipal services (Kemeter, 2009: 490). In both Slovenia and Croatia, it is emphasised that relatively small municipalities should connect in order to provide high-quality, low-cost performance of individual activities in large areas.

One of the public-private partnership forms, which are widely used in many developed countries, and they are gaining in importance also in the Slovenian and Croatian municipalities, is the model of build-operate-transfer or $\mathrm{BOT}^{11}$. This is a model of partnership relationships between the private and public sectors, and it is characterised by having a legal basis in a concession and in the so-called project funding. On the basis of a concession contract, the concessionaire funds the construction of an infrastructure facility; he possesses it and manages it for a certain period of time. After expiration of this period, he passes the ownership of this facility to the state or local community. This type of funding is very 


\section{LEX LOCALIS - JOURNAL OF LOCAL SELF GOVERNMENT B. Grafenauer \& M. Klarić: Alternative Service Delivery Arrangements at the Municipal Level in Slovenia and Croatia}

complicated because it requires all participants to provide a detailed economic and financial feasibility assessment of the project. In the BOT project, most risks are distributed among private investors. Therefore, the prior assessment and analysis of the construction, and the method or form of the project implementation are required. The private sector participates in funding economic infrastructure based on the quality assessment of the project itself, on the basis of the assessment of the expected future cash inflows (with regard to the anticipated service prices), and, of course, on the basis of the capital efficiency assessment of the invested funds, innovativeness, and management ability. It is important for a local community to relieve major risks that it would otherwise bear. In return for the risks, the local community grants a natural monopoly right to the concessionaire. At the end of the contractually determined duration of the concession period (of 20 to 30 years), the ownership of the infrastructure facility shall be transferred back to the local community. It may again decide to put it under concession management, or to select some other method of management to provide public goods to users. It is important for the local community that the concessionaire bears the demand risk that encourages him to be especially motivated for maximum capacity utilisation, expense optimisation, and for the efficiency of the entire project.

\section{Notes}

${ }^{1}$ The contemporary institute for public-private partnerships arises from the emergence of neoinstitutionalism, see North, Douglass Cecil. Institutions, institutional change, and economic performance. Cambridge, New York: Cambridge University Press, 1990. On the shift of the public service provision from traditional forms to privatisation, see Manning, 1998.

2 Public-Private Partnership Act, OJ RS, No. 127/2006 of 7 December 2006, came into force on 7 March 2007.

3 Public-Private Partnership Act (Official Journal of the Republic of Croatia, No. 129/2008, came into force on 15 November 2008.

${ }^{4}$ Public-Private Partnerships, Avaliable at: http://ec.europa.eu/regional_policy/sources/

docgener/guides/pppguide.htm, 3/14/2010.

5 In Croatia, the Government Guidelines for the Use of Contractual Forms of Public-Private Partnership were adopted (Official Journal of the Republic of Croatia, No. 98/2006). For a critical review of these guidelines see Perko Separovic, 2007.

In Slovenia, Faculty of Economics, University of Ljubljana, published a Handbook on cooperation between the public and private sectors in financing the construction of municipal infrastructure and on the provision of services of general economic interest in 2002 (authors: Mojmir Mrak and Igor Glavan). The Office of the Government of the Republic of Slovenia for Local Self-Government and Regional Policy issued the following publication in 2005: Project Funding: An Alternative Form of Funding Infrastructure Facilities (authors: Maja Gazvoda, Mojmir Mrak).

${ }^{6}$ Under the provisions of the Slovenian Municipality Funding Act, municipalities may borrow only within the amount that together with the existing debt status, the loan does not exceed $20 \%$ of the realized revenue from the annual balance sheet prior to borrowing, and if annual principal and interest repayments do not exceed $5 \%$ of the realised budget revenues for the year prior to borrowing. Under the provisions of the Croatian Finance Act, the amount of the 
total annual indebtedness or liabilities may amount to no more than 20 realised revenues in the year prior to borrowing

${ }^{7}$ Here are two examples of such arrangements. The Slovenian Environment Protection Act enumerates the mandatory public utilities for environment protection: drinking water supply, drainage and wastewater treatment, municipal waste collection and transport, scrap disposal and municipal waste disposal, public area planning and cleaning. The Public Roads Act provides for the maintenance of public roads as a mandatory service of general economic interest.

${ }^{8}$ For example, this is the Public Institution Management Act in the field of culture (2001).

${ }^{9}$ It needs to be pointed out to the provision of Article 17 of the Public Procurement Act (Official Journal of the Republic of Slovenia, No. 128/2006) that this Act does not apply to service concessions

10 Avaliable at: http://www.mf.gov.si/si/javno_zasebno_partnerstvo/aktualni_projekti_in_ statisticna_porocila/, 2/22/2010.

11 The BOT model has acquired an important role in international practice over the last few decades (especially since the 1980s). Its role is so important that the United Nation Industrial Development Organization has issued Guidelines for Infrastructure Development Through Build-Operate-Transfer (BOT) projects).

\section{References}

Bohinc, R., Mužina, A. \& Tičar, B. (2007) Zakon o javno-zasebnem partnerstvu s pojasnili (Ljubljana: Nebra).

Brezovnik, B. (2008) Izvajanje javnih služb in javno-zasebno partnerstvo (Maribor: Inštitut za lokalno samoupravo in javna naročila Maribor).

Gazvoda, M. \& Mrak, M. (2005) Projektno financiranje: alternativna oblika financiranja infrastrukturnih objektov (Ljubljana: Služba Vlade Republike Slovenije za lokalno samoupravo in regionalno politiko).

Gjidara, M. \& Šimenc, N. (2000) Koncesije i drugi načini povjeravanja javnih usluga pravnim i fizičkim osobama, Pravo u gospodarstvu, 39(5), pp. 82-92.

Grafenauer, B. \& Brezovnik, B. (2006) Javno-zasebno partnerstvo v občinah, Gospodarski subjekti na trgu - posodobitev gospodarskega prava (Maribor: Pravna fakulteta Maribor, Inštitut za gospodarsko pravo Maribor).

Grafenauer, B. (2009) An Analysis of the Provision of Local Public Utility Services by Way of Illustration of Two Slovenian Municipalities, Lex Localis - Journal of Local Self-Government, 7(2), pp. 209-219.

Haarmeyer, D. \& Mody, A. (1998) Financing and Sanitation Projects - The Unique Risk, Public Policy for the Private Sector, 151, received at: http://rru.worldbank.org/ documents/publicpolicyjournal/151haarm.pdf, 8/11/2010.

Kemeter, D. (2009) Stanje u komunalnim djelatnostima, Hrvatska javna uprava, 9(2), pp. 471-493.

Krajnc, V., Kerševan, E., Plauštajner, K. \& Prelič, S. (2009) Zakon o javno-zasebnem partnerstvu s komentarjem (Ljubljana: GV Založba).

Krajnc, V. (2009) EU and International Organisations Rules on Public-Private Partnerships, Lex Localis - Journal of Local Self-Government, 7(2), pp. 197-207.

Manning, N. (1998) Unbundling the State Autonomous Agencies and Service Delivery (Washington D. C.: World Bank).

Mrak, M. \& Glavan, I. (2002) Priročnik o sodelovanju zasebnega in javnega sektorja pri financiranju izgradnje komunalne infrastrukture in opravljanju javne gospodarske službe (Ljubljana: Ekonomska fakulteta Ljubljana). 
North, D. C. (1990) Institutions, institutional change, and economic performance (Cambridge, New York: Cambridge University Press).

Perko-Šeparović, I. (2007) Controversiality of Risk Transfer in Public-Private Partnerships, Hrvatska javna uprava, 7(4), pp. 943-969.

Pirnat R. (2007) Podelitev koncesije po Zakonu o javno-zasebnem partnerstvu, Podjetje in delo, (33(6-7), pp. 1185-1198.

Sarvan, D. (2008) Obavljanje komunalnih djelatnosti kao javne službe, Hrvatska javna uprava, 8(4), pp. 1055-1086.

Šimović, J., Lugarić-Rogić, T., Šimović, H. \& Vuletić-Antić, B. (2007) Public Private Partnership as a Non-Fiscal Instrument of Financing the Public Interests, Hrvatska javna uprava, 7(1), pp. 171-201.

Smyth, P. \& Wearing, M. (2002) After the Welfare State? Welfare Governance and the Communitarian Revival, In: Bell, S. (ed) Economic Governance and Institutional Dynamics (Oxford - Melbourne: Oxford University Press).

Tičar, B. (2007) Nov pravni institut: javno-zasebno partnerstvo, Podjetje in delo, 33(1), pp. $58-70$

Tičar, B. \& Zajc, K. (2010) Public-Private Partnerships in Slovenia: Recent Developments and Perspectives, Review of Central and East European Law, 35(2), pp. 191-215.

Wilson, W. (1887) The study of Administration, Political Science Quarterly, 2(2), pp. 197222. 